\title{
SINGLE TO MULTI-CHANNEL COCHLEAR REIMPLANTATION AFTER 21 YEARS: CASE REPORT
}

\section{Johannes Schnabl ${ }^{1}$, Astrid Wolf-Magele ${ }^{1}$, Viktor Koci ${ }^{2}$, Volker Schartinger ${ }^{1}$, Andreas Markl ${ }^{1}$, Georg Sprinzl ${ }^{1}$}

${ }^{1}$ Department of Otorhinolaryngology, Innsbruck Medical University, Innsbruck, Austria

${ }^{2}$ Department of Hearing, Speech and Voice Disorders, Innsbruck Medical University, Innsbruck, Austria

Corresponding author: Georg Sprinzl, Department of Otorhinolaryngology, Innsbruck Medical University, Innsbruck, Austria, e-mail: georg.sprinzl@i-med.ac.at

Abstract

Background: In the literature cochlear reimplantation is described as a possible surgical procedure and the change from a single to a multichannel device is associated with audiological improvement.

Material and Methods: A 47 year old male caucasian patient presented after cochlear implantation 21 years ago. Lacking any benefit from the old single-channel implant over the last few years, the patient no longer used the device. The old cochlear implant was changed for a modern multichannel unit.

Results: The patient showed a great improvement in hearing threshold and his quality of life with the new device.

Conclusions: This case justifies the reimplantation of patients who have been implanted more than 20 years ago.

Key words: Cochlear reimplantation • ball electrode

\section{REIMPLANTACIÓN COCLEAR DE MONOCANAL A MULTICANAL DESPUÉS DE 21} AÑOS: INFORME DE UN CASO CLÍNICO

\section{Resumen}

Antecedentes: En la literatura, se describe la reimplantación coclear como un posible procedimiento quirúrgico y el cambio de un aparato monocanal a multicanal está asociado a la mejora audiológica.

Materiales y métodos: Se presentó a un paciente caucásico de 47 años al que se colocó un implante coclear 21 años antes. Como el implante monocanal no le había proporcionado beneficios durante los últimos años, el paciente ya no usaba el aparato. Se le cambió el implante coclear antiguo por una unidad multicanal moderna.

Resultados: El paciente mostró una gran mejora en el umbral auditivo y en su calidad de vida con el nuevo aparato.

Conclusiones: Este caso justifica la reimplantación de pacientes a los que se colocó un implante hace más de 20 años.

Palabras clave: reimplantación coclear • electrodo de bola

\section{ОТ ОДНО- ДО МНОГОКАНАЛЬНОЙ КОХЛЕАРНОЙ РЕИМПЛАНТАЦИИ ПОСЛЕ 21 ГОДА: СИТУАЦИОННЫЙ ДОКЛАД}

\section{Резюме}

Предпосылки: В литературе кохлеарная реимлантация описана как возможная хирургическая процедура, а замена одно- на многоканальный аппарат связана с аудиологическими усовершенствованиями.

Материалы и методы: Представлен 47-летний пациент - белый мужчина после 21-летней кохлеарной имплантации. Не получая за последние несколько лет от старого одноканального импланта никакой пользы, пациент перестал пользоваться аппаратом. Старый кохлеарный имплант был заменен на современный многоканальный аппарат.

Результаты: У пациента с новым аппаратом произошло огромное улучшение порогов слуха и качества его жизни. 
Заключение: Этот случай утверждает правильность реимплантации пациентов, которые были имлантированы более 20 лет назад.

Ключевые слова: кохлеарная реимплантация • шариковый электрод

\section{Background}

Dr William House first introduced cochlear implantation 35 years ago as a treatment for patients with sensorineural hearing loss [1]. Since then, cochlear implants have developed from single-electrode devices to multi-electrode devices with complex digital signal processing. Previous studies have demonstrated huge benefits in speech recognition with multi-electrode devices compared to single channel devices [2,3]. We have been implanting cochlear implants (CIs) in our clinic since 1986. Due to the electronic nature of CIs, device failure can sometimes occur. In addition, continuous improvements to CI technology have resulted in substantially more sophisticated new implants. For these and other reasons, reimplantation is sometimes necessary and/or desirable.

The first study concerning CI reimplantation was published in 1985 [4]. Since then several reports about cochlear reimplantation have appeared in the literature [5-9]. All of these publications state that such surgery is possible in general, as well as the fact that the audiologic performance of reimplanted patients is equal to or better than it was before the failure occurred. Although the surgical technique for cochlear reimplantation is not markedly different than that of an initial CI, some complications, such as ossification, have been observed and should therefore be taken into consideration when attempting this procedure.

The aim of this case report is to show the surgical possibility of cochlear reimplantation and its audiological benefits with a multichannel CI after 21 years.

\section{Case Report}

\section{History of the patient}

A 47-year old patient presented with congenital or infantile acquired profound hearing loss. He began wearing conventional hearing aids at the age of 4 years, with marginal benefit. He studied sign language in a special school. In 1989 he was implanted with a two-channel cochlear implant (Vienna Implant; Med-El, Innsbruck, Austria). Postoperatively, the patient had problems with vertigo and headaches, and was disappointed with the audiological results of his first CI. He wore the speech processor only at home and not while working because of the adverse noise and subsequent headaches. This patient was ashamed of his speech and hearing disorders and therefore decided to retire. At the time he came to us, he did not wear his CI any more. The implant was still working but no new external speech processor able to stimulate the old implant was available and no spare parts to repair the old speech processor were available. He asked for a new, improved implant because of the disappointing audiological results with his old one.

Figure 1 presents the patient's audiogram from March 2010, showing profound hearing loss.

After performing a CT scan (Figure 2) and after the patient gave written informed consent, we decided to implant him with a new CI.

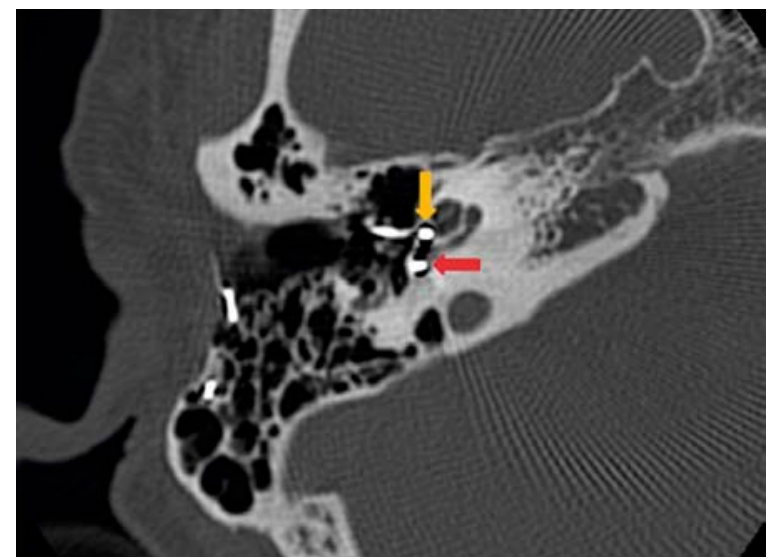

Figure 2. Preoperative, axial view CT scan of the right temporal bone with the ball electrode at the apex of the cochlea (yellow arrow) and near the round window (red arrow).

Figure 1. Preoperative audiogram.
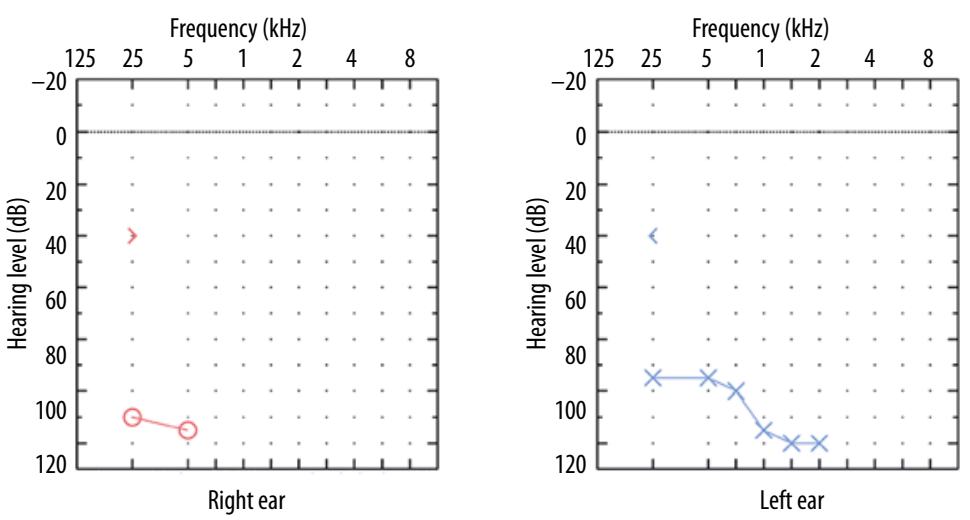


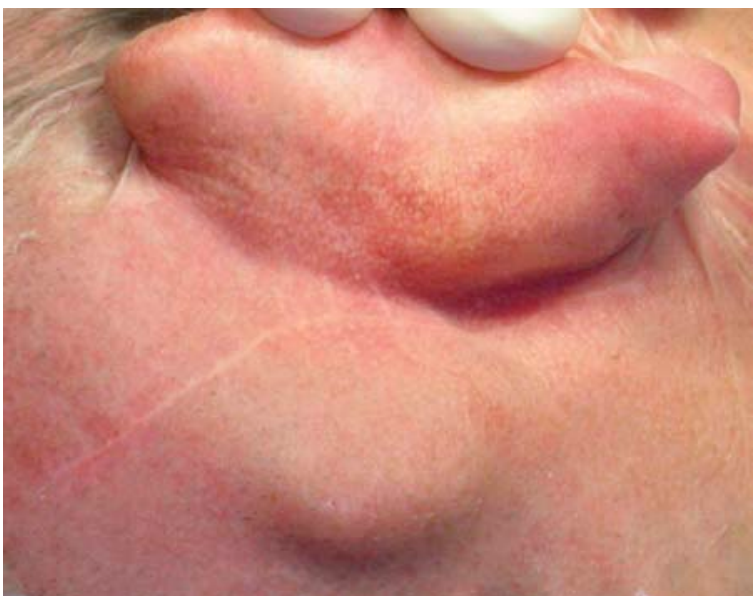

Figure 3. Preoperative retroauricular photo of the old scar and implant.

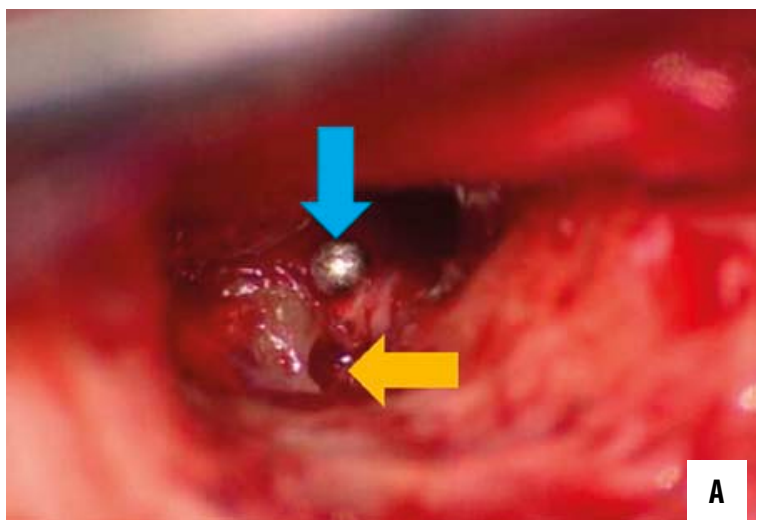

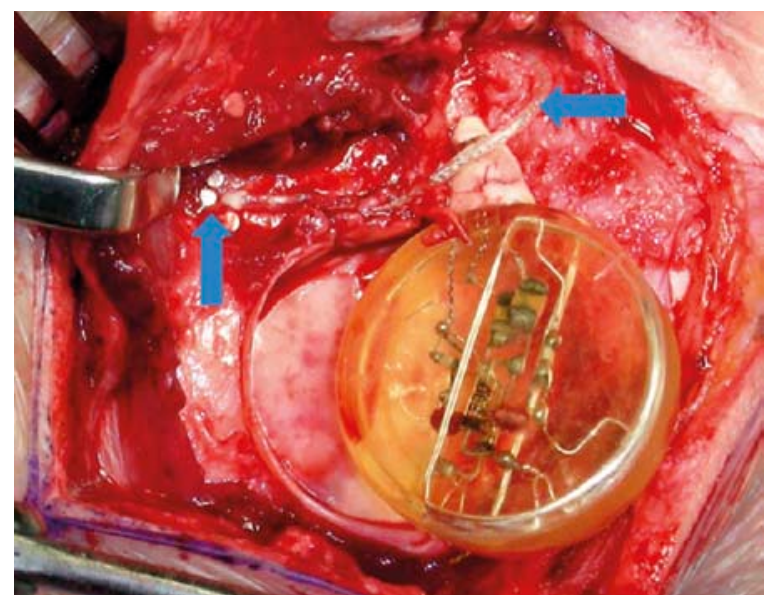

Figure 4. The old implant with the reference electrode (blue arrows).

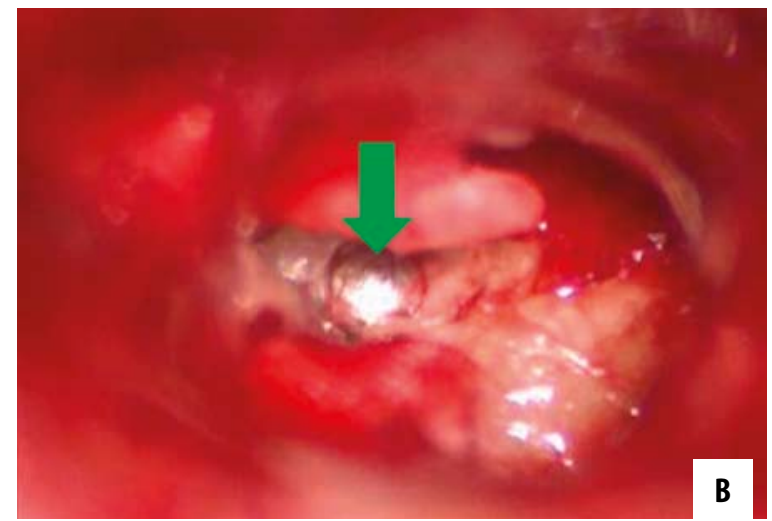

Figure 5. (A) The ball electrode (blue arrow) and its former placement niche (yellow arrow) on the promontorium. (B) The ball electrode at the apex of the cochlea.
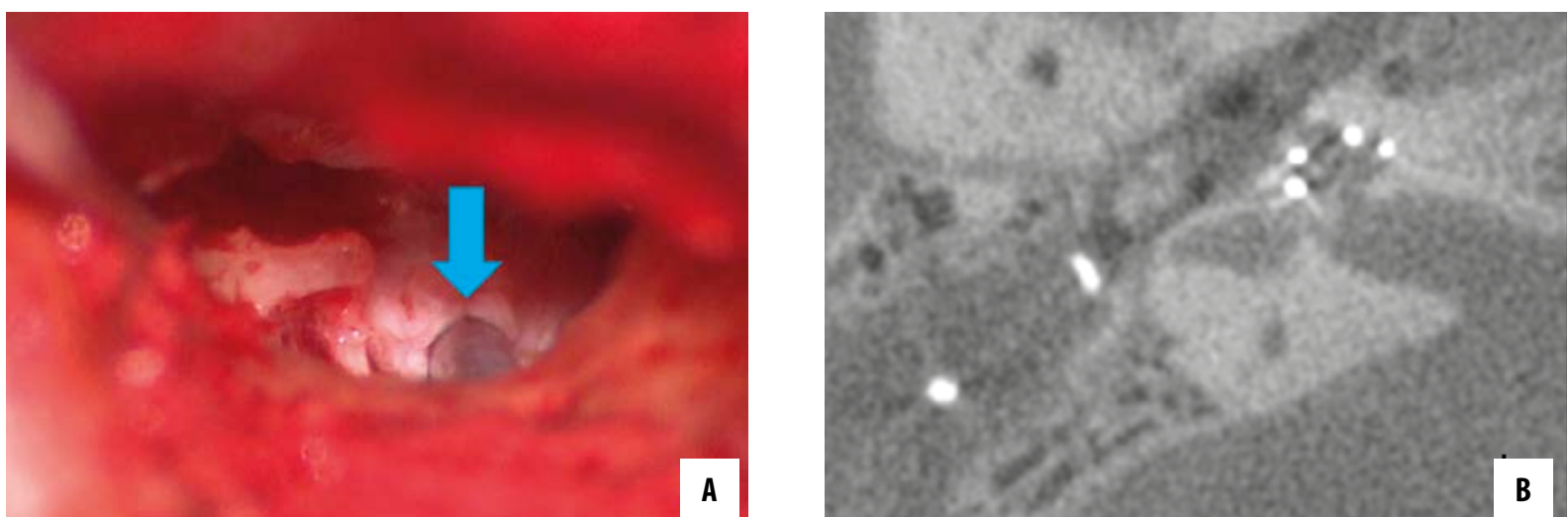

Figure 6. (A) The implanted electrode (blue arrow). (B) A DVT scan for postoperative monitoring of the electrode's position.

\section{Surgery}

Under general anesthesia, the region of the old scar (Figure 3) was injected with local anesthetic. After opening the scar, the old implant was visualised. The reference electrode (Figure 4) from the Vienna CI (a two-channel implant in which one ball electrode is placed at the apex of the cochlea and another in the field of the round window) could be removed easily. The electrode was located at the epitympanon near the round window, whose membrane was intact (Figure 5A). The electrode placed at the apex of the cochlea (Figure 5B) could be removed after drilling the bone (due to extensive bone growth, the electrode was surrounded by bone).

A mastoidectomy and a posterior tympanotomy approach were then performed. After drilling a bed and placing the implant (Med-El Sonata, standard length) in it, we were able to fully insert the electrode through the round window (Figure 6A). Intraoperative measurements were found to be correct (the stapedius reflex could be activated and impedance audiometry and ARTs were in the 

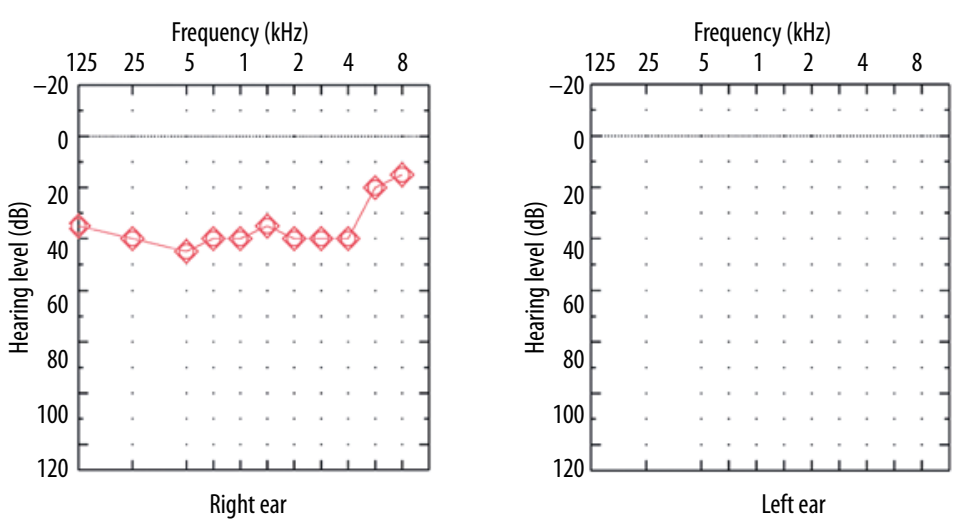

Figure 7. Aided, free-field hearing threshold. normal range). At the end of the surgery, the wound was sutured.

Two days after surgery, a DVT scan was done to monitor the position of the electrode (Figure 6B).

\section{Audiological outcome}

Six weeks after implantation, we activated the CI and initiated adjustments. Figure 7 shows the audiogram of the patient's aided hearing threshold in free field, 8 months after reimplantation. Pre- or postoperative speech audiometry was not possible due to severe prelingual hearing impairment and never-acquired speech (speech score was $0 \%$ ).

\section{General outcome}

The patient reported an enormous improvement in his quality of life. He is now able to receive new impressions like birds singing and chirping, the noise of the wind, and music. He is also better able to distinguish letters and sibilants, with the result being that he can now better control his own voice and is beginning to acquire speech.

\section{Discussion}

Cochlear reimplantation is a practicable and potentially successful operation to help patients with non- or malfunctioning CIs. However, the surgical procedure can present challenges, particularly if structures are cicatrised or ossified [10]. In our case, the tricky part of the surgery involved the removal of the ball electrodes, since the electrode near the apex was nearly completely ossified.

The reasons for performing cochlear reimplantation include device failure, the desire to upgrade to a newer technology, and infection. Naturally, as CI technology has become more sophisticated, the relative number of device failures has also decreased.

Animal studies [11,12] involving explantation of a CI and subsequent reimplantation have suggested reimplantation is generally safe, with no significant additional damage to cochlear structures above that incurred from the first implantation. However, Jackler et al. [11] suggests that reimplantation should not be delayed after explantation of a CI.

Long-term retrospective studies [6,10,13-16] have shown postoperative performance following reimplantation to be equal to or better than performance with the initial implant before its failure. These studies also revealed reimplantation to be a safe procedure, with no damage to cochlear structures that would prevent the patient being provided with an upgraded device [6].

Our patient's audiologic outcome is astonishing and correlates with the audiologic outcomes described by Coté et al. [7]. We can conclude that cochlear reimplantation is an effective and safe procedure, even if the original implantation was done more than 20 years ago.

\section{Acknowledgement}

We thank Noelani Peet for medical writing assistance.

\section{Conflict of interest}

All authors declare that the manuscript has not been published previously nor under review by another journal. The paper has not been presented to any professional society. All authors declare that neither financial interests nor financial support by companies exist.

\section{References:}

1. House WF: Cochlear implants. Ann Otol Rhinol Laryngol, 1976; 85(Suppl.27): 1-93

2. Rubinstein JT, Parkinson WS, Lowder MW et al: Single-channel to multichannel conversions in adult cochlear implant subjects. Am J Otol, 1998; 19: 461-66
3. Hamzavi JS, Baumgartner WD, Adunka O et al: Audiological performance with cochlear reimplantation from analogue single-channel implants to digital multi-channel devices. Audiology, 2000; 39: 305-10 
4. Hochmair-Desoyer I, Burian K: Reimplantation of a molded scala tympani electrode: impact on psychophysical and speech discrimination abilities. Ann Otol Rhinol Laryngol, 1985; 94: $65-70$

5. Gantz BJ, Lowder MW, McCabe BF: Audiologic results following reimplantation of cochlear implants. Ann Otol Rhinol Laryngol Suppl, 1989; 142: 12-16

6. Alexiades G, Roland JT Jr, Fishman AJ et al: Cochlear reimplantation: surgical techniques and functional results. Laryngoscope, 2001; 111: 1608-13

7. Cote $\mathrm{M}$, Ferron P, Bergeron $\mathrm{F}$ et al: Cochlear reimplantation: causes of failure, outcomes, and audiologic performance. Laryngoscope, 2007; 117: 1225-35

8. Henson AM, Slattery WH, Luxford WM et al: Cochlear implant performance after reimplantation: a multicenter study. Am J Otol, 1999; 20: 56-64

9. Sorrentino $\mathrm{T}$, Cote $\mathrm{M}$, Eter $\mathrm{E}$ et al: Cochlear reimplantations: technical and surgical failures. Acta Otolaryngol, 2009; 129: $380-84$
10. Orus DC, Venegas Pizarro MP, De Juan BJ et al: [Cochlear reimplantation in the same ear: Findings, peculiarities of the surgical technique and complications]. Acta Otorrinolaringol Esp, 2010; 61: 106-17

11. Jackler RK, Leake PA, McKerrow WS: Cochlear implant revision: effects of reimplantation on the cochlea. Ann Otol Rhinol Laryngol, 1989; 98: 813-20

12. Greenberg AB, Myers MW, Hartshorn DO et al: Cochlear electrode reimplantation in the guinea pig. Hear Res, 1992; 61: 19-23

13. Trotter MI, Backhouse S, Wagstaff $S$ et al: Classification of cochlear implant failures and explantation: the Melbourne experience, 1982-2006. Cochlear Implants Int, 2009; 10(Suppl.1): $105-10$

14. Yu LS, Chen F, Zheng HW et al: [Cochlear reimplantation]. Zhonghua Er Bi Yan Hou Ke Za Zhi, 2004; 39: 598-601

15. Woolford TJ, Saeed SR, Boyd P et al: Cochlear reimplantation. Ann Otol Rhinol Laryngol Suppl, 1995; 166: 449-53

16. Saeed SR, Ramsden RT, Hartley C et al: Cochlear reimplantation. J Laryngol Otol, 1995; 109: 980-85 